\title{
Increased Cell Wall Porosity in Saccharomyces cerevisiae after Treatment with Dithiothreitol or EDTA
}

\author{
By J. G. DE NOBEL, * C. DIJKERS, E. HOOIJBERG AND F. M. KLIS \\ Department of Molecular Cell Biology, Biotechnology Center, University of Amsterdam, \\ Kruislaan 318, 1098 SM Amsterdam, The Netherlands
}

(Received 21 October 1988; revised 20 February 1989; accepted 20 March 1989)

\begin{abstract}
Intact cells of Saccharomyces cerevisiae were able to endocytose FITC-dextrans of $70 \mathrm{kDa}$, but not of $150 \mathrm{kDa}$, whereas spheroplasts took up both components. The rate of uptake of $70 \mathrm{kDa}$ dextrans by spheroplasts was about three times higher than that by intact cells. Pretreatment of intact cells with dithiothreitol (DTT) or EDTA increased the rate of uptake of $70 \mathrm{kDa}$ dextrans considerably, but $150 \mathrm{kDa}$ dextrans were still excluded. Release of periplasmic invertase activity into the medium by glucose-derepressed cells was negligible in control cell suspensions, but was strongly stimulated in the presence of DTT. The released invertase had an apparent molecular mass of $320 \mathrm{kDa}$, indicating that the dimeric form was released. In the presence of EDTA only a slight increase in the release of invertase was observed. Pretreatment with DTT was accompanied by an increased loss of cell wall proteins. This suggests that the loss of mannoproteins, in combination with a more general opening up of the wall by reducing disulphide bridges, increases cell wall porosity. It is argued from the Stokes radius of $70 \mathrm{kDa}$ dextran $(5.8 \mathrm{~nm})$ that yeast cell walls are, in principle, permeable to globular proteins with a molecular mass up to $400 \mathrm{kDa}$.
\end{abstract}

\section{INTRODUCTION}

Saccharomyces cerevisiae offers many advantages as a host for the production of heterologous proteins (Das \& Schultz, 1987), but its rigid cell wall prevents the easy recovery of such proteins. Therefore, secretion of heterologous proteins into the culture fluid is highly advantageous (Nishizawa et al., 1987). Efficient plasma membrane passage can be obtained by using yeast secretion signals (Smith et al., 1985b). Efficient cell wall passage, however, seems to depend on the molecular size of the proteins. For instance, Wood et al. (1985) showed that transformed yeast cells secrete Ig light chains $(28 \mathrm{kDa})$ more efficiently than Ig heavy chains $(63 \mathrm{kDa})$. Data about maximum molecular sizes permitting passage through the cell wall are contradictory. Scherrer et al. (1974) state $700 \mathrm{Da}$ as the maximum size allowing a molecule to diffuse freely through the yeast cell wall. However, there are numerous examples of secretion of larger molecules into the medium, although with variable efficiencies, such as the heterologous proteins interferon (20 kDa; Hitzeman et al., 1983), $\alpha$-amylase (42 kDa; Rothstein et al., 1984), Ig-chains (28 or $63 \mathrm{kDa}$; Wood et al., 1985) and prochymosin (60 kDa; Smith et al., 1985 b). Basu et al. (1986) even found the secretion of a $320 \mathrm{kDa}$ homologous protein in an auxotrophic yeast mutant.

Zlotnik et al. (1984) used the susceptibility of yeast to lytic enzymes, $\beta$-glucanase ( $58 \mathrm{kDa}$ ) and peroxidase $(40 \mathrm{kDa})$, as a measure of cell wall porosity. They showed that the mannoproteins in the yeast cell wall act as a barrier to these enzymes. In this work, we have used the uptake of FITC-conjugated macromolecules (FITC-dextrans) and the release of the periplasmic enzyme invertase as indications of yeast cell wall porosity.

Abbreviations: BSA, bovine serum albumin; FD, FITC-dextran; FITC, fluorescein isothiocyanate. 


\section{METHODS}

Yeast strain and growth. Saccharomyces cerevisiae X2180-1A was obtained from the Yeast Genetic Stock Center, Berkeley, California, USA, and grown at $28^{\circ} \mathrm{C}$ in YPG medium $[1 \%(\mathrm{w} / \mathrm{v})$ yeast extract, Gibco; $1 \%(w / v)$ bactopeptone, Difco; $3 \%(w / v)$ glucose]. Cells were harvested in the early exponential phase $\left(\mathrm{OD}_{530}\right.$ approximately 2 ).

Spheroplast formation. Intact cells $\left(10^{9} \mathrm{ml}^{-1}\right)$ were converted to spheroplasts by incubation for $1 \mathrm{~h}$ at $37^{\circ} \mathrm{C}$ with a $0.125 \mathrm{mg} \mathrm{ml}^{-1}$ solution of Zymolyase $20 \mathrm{~T}$ (Kirin Brewery) in $10 \mathrm{~mm}$-Tris/ $\mathrm{HCl}, \mathrm{pH} \mathrm{7.5}$, containing $1 \mathrm{M}$-sorbitol. Spheroplast formation was followed by phase-contrast microscopy.

Internalization of FITC-dextran as determined by gel filtration. Cells $\left(10^{9} \mathrm{ml}^{-1}\right)$ were incubated for $30 \mathrm{~min}$ at $37^{\circ} \mathrm{C}$ in the presence of $25 \mathrm{mg}$ FITC-dextran of $70 \mathrm{kDa}$ (FD70) per $\mathrm{ml} 10 \mathrm{mM}$-Tris/HCl, $\mathrm{pH} \mathrm{7.8.} \mathrm{As} \mathrm{a} \mathrm{control,} \mathrm{cells} \mathrm{were}$

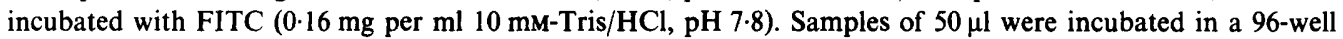
microtitre plate and shaken at 250 r.p.m. During incubation the $\mathrm{pH}$ remained stable. This is important, because with insufficient aeration the $\mathrm{pH}$ tends to drop below 6, which results in FITC becoming uncharged; free FITC if present can then easily pass the cell membrane. After incubation, the cells were washed with $10 \mathrm{mM}-\mathrm{Tris} / \mathrm{HCl}$, $\mathrm{pH} 7 \cdot 8$, and converted to spheroplasts. Spheroplasts, washed with $10 \mathrm{~mm}-\mathrm{Tris} / \mathrm{HCl}, \mathrm{pH} \mathrm{7.8}$, containing $1 \mathrm{M}-$ sorbitol, were lysed in distilled water. Subsequently, the lysate was precipitated in $80 \%(\mathrm{v} / \mathrm{v})$ ethanol for $16 \mathrm{~h}$ at $4{ }^{\circ} \mathrm{C}$. After washing the precipitate with $96 \%(\mathrm{v} / \mathrm{v})$ ethanol, it was resuspended in $10 \mathrm{~mm}-\mathrm{Tris} / \mathrm{HCl}, \mathrm{pH} 7 \cdot 8$, and centrifuged for $1 \mathrm{~min}$ at $10000 \mathrm{~g}$. The supernatant was filtered (Nihon Millipore HV $0.45 \mu \mathrm{m}, \mathrm{Kogyo} \mathrm{KK}$ ), and applied to a Superose 6 column $\left(10 \times 300 \mathrm{~mm}\right.$; Pharmacia), equilibrated and run in $150 \mathrm{~mm}-\mathrm{Na}_{2} \mathrm{SO}_{4}, 10 \mathrm{~mm}$ sodium phosphate buffer, $\mathrm{pH} 7 \cdot 4,10 \mathrm{mM}$-n-octyl- $\beta$-D glucopyranoside at a flow of $0.25 \mathrm{ml} \mathrm{min}{ }^{-1}$. Fractions of $1 \mathrm{ml}$ were collected and assayed for FITC fluorescence. When spheroplasts were used for FITC-dextran uptake experiments, incubation and washings were performed in the presence of $1 \mathrm{M}$-sorbitol.

Effect of DTT, EDTA and spheroplasting on FITC-dextran uptake. Cells $\left(5 \times 10^{8} \mathrm{ml}^{-1}\right)$ were treated for $30 \mathrm{~min}$ at $4{ }^{\circ} \mathrm{C}$ with $100 \mathrm{~mm}$-DTT or $250 \mathrm{~mm}$-EDTA in $20 \mathrm{~mm}$-HEPES, pH 7.2. They were then washed three times with $20 \mathrm{mM}$-HEPES, $\mathrm{pH} 7 \cdot 2$, containing $0 \cdot 14 \mathrm{M}-\mathrm{NaCl}$. Treated cells were incubated for $30 \mathrm{~min}$ at $37^{\circ} \mathrm{C}$ or $0{ }^{\circ} \mathrm{C}$ in YPG buffered with $20 \mathrm{~mm}$-HEPES, pH 7.2, and containing $25 \mathrm{mg}$ FITC-dextran $\mathrm{ml}^{-1}$. The pH remained stable during incubation. After incubation, the cells were washed at least five times with 20 mM-HEPES, pH $7 \cdot 2$, containing $0.14 \mathrm{M}-\mathrm{NaCl}$ to remove non-internalized FITC-dextran. This was microscopically checked with an Olympus phase-contrast microscope with an epifluorescence attachment. Washed cells were lysed with $0 \cdot 125 \mathrm{mg}$ Zymolyase $20 \mathrm{~T}$ per $\mathrm{ml} 10 \mathrm{mM}-\mathrm{Tris} / \mathrm{HCl}, \mathrm{pH} 7.8$, for $30 \mathrm{~min}$ at $37^{\circ} \mathrm{C}$. The lysates were taken up in $2.5 \mathrm{ml} 0.08 \%$ $(\mathrm{w} / \mathrm{v}) \mathrm{SDS}$ in $10 \mathrm{~mm}$ Tris/ $\mathrm{HCl}, \mathrm{pH} \mathrm{7.8}$, and assayed fluorometrically. Uptake of FITC-dextrans was defined as fluorescence after incubation at $37^{\circ} \mathrm{C}$ minus fluorescence after incubation at $0{ }^{\circ} \mathrm{C}$. When spheroplasts were used in uptake experiments, incubation and washings were performed in the presence of $1 \mathrm{M}$-sorbitol.

Release of invertase activity. Cells were derepressed by transferring early exponential phase cells from YPG medium to the same medium with $0 \cdot 2 \%(\mathrm{w} / \mathrm{v})$ glucose. Cells were incubated for $30 \mathrm{~min}$ at $28{ }^{\circ} \mathrm{C}$. As a control, cells were pelleted and resuspended in their own medium. After induction, cells were harvested, washed and treated with $20 \mathrm{~mm}$-DTT or $100 \mathrm{~mm}$-EDTA in $10 \mathrm{~mm}$-Tris/ $\mathrm{HCl}, \mathrm{pH} 7 \cdot 8$, for $30 \mathrm{~min}$ at $4{ }^{\circ} \mathrm{C}$. Treated cells were pelleted for $5 \mathrm{~min}$ at $10000 \mathrm{~g}$. The resulting supernatant fraction was dialysed against distilled water and assayed for released invertase activity. The pelleted cells were washed with $10 \mathrm{mM}-\mathrm{Tris} / \mathrm{HCl}, \mathrm{pH} 7 \cdot 5$, containing $1 \mathrm{M}$-sorbitol, and subsequently treated with Zymolyase 20T to produce spheroplasts. After pelleting the spheroplasts, the supernatant was dialysed against distilled water and assayed for retained periplasmic invertase activity. Zymolyase $20 \mathrm{~T}$ itself did not contain detectable invertase activity.

Invertase assay. Invertase activity was assayed with sucrose as substrate as described by Goldstein \& Lampen (1975) except that the resulting reducing sugars were determined by the Nelson-Somogyi method (Spiro, 1966). One unit of invertase activity was defined as the amount of enzyme which hydrolyses sucrose to produce one $\mu \mathrm{mol}$ glucose $\min ^{-1}$ at $30^{\circ} \mathrm{C}$ and $\mathrm{pH} 5$.

HP gel filtration of invertase. A TSK G4000SW column $\left(7.5 \times 600 \mathrm{~mm}\right.$; LKB) eluted with $100 \mathrm{~mm}-\mathrm{Na}_{2} \mathrm{SO}_{4}$, $20 \mathrm{mM}$-sodium phosphate buffer, $\mathrm{pH} 6.8$, at a flow rate of $0.25 \mathrm{ml} \mathrm{min}^{-1}$ was used for gel filtration. Fractions of $1 \mathrm{ml}$ were collected and assayed for invertase activity.

Fluorometry. Fluorometry was performed with a Perkin-Elmer LS-5 fluorometer. Emission was measured at a wavelength of $526 \mathrm{~nm}$ (slit $20 \mathrm{~nm}$ ) with an excitation wavelength of $496 \mathrm{~nm}$ (slit $2.5 \mathrm{~nm}$ ).

Viability. Cell viability was determined by plating a dilution series of (treated) cells on YPG-agar $(2 \%$, w/v, agar in YPG medium). After $2 \mathrm{~d}$ of growth at $28^{\circ} \mathrm{C}$, colonies were counted.

$S D S-P A G E$. SDS-electrophoresis in $2 \cdot 2-20 \%$ polyacrylamide gradient gels was performed as described by Laemmli (1970). Gels were stained by silver staining as described by Morrissey (1981) except that they were soaked for $30 \mathrm{~min}$ after protein fixation in a $1 \%(\mathrm{w} / \mathrm{v})$ solution of periodic acid in $3 \%(\mathrm{v} / \mathrm{v})$ acetic acid to enhance visualization of glycoproteins by subsequent silver staining.

Protein assay. Protein was assayed with bicinchoninic acid (reagents from Pierce; Smith et al., 1985a) with BSA as a standard. 
Chemicals. FD70 (lot 97F-0599; $71.6 \mathrm{kDa} ; 3 \mathrm{mmol}$ FITC per mol glucose) and FD150 (lot 126F-0144; $148.9 \mathrm{kDa} ; 5 \mathrm{mmol}$ FITC per mol glucose) were from Sigma. BSA, DTT and cycloheximide were also from Sigma; FITC was from Merck.

\section{RESULTS}

\section{FITC-dextran uptake}

The following experiments demonstrate that cells of $S$. cerevisiae are capable of internalizing intact FD70. Spheroplasts were incubated with FD70, washed and subsequently lysed. The lysate was ethanol-precipitated to remove possible impurities. The precipitate was resuspended in buffer and applied to a Superose 6 gel filtration column (size exclusion for globular proteins approximately $2 \times 10^{7} \mathrm{Da}$ ), and the fluorescence of the collected fractions was measured. The elution pattern (Fig. $1 b$ ) showed that the material that was internalized eluted at the same position as FD70 (Fig. 1a). Intact cells were incubated with FD70, washed, converted to spheroplasts and again washed. The spheroplasts were lysed; the lysate was ethanol-precipitated and the ethanol-insoluble material was applied to the gel filtration column. It also eluted at the same position as FD70 (Fig. 1c), indicating that intact cells also internalized FD70.

Preston et al. (1987) showed that commercially available FD can be contaminated with free FITC and other low-molecular-mass fluorescent compounds, which might be responsible for apparent uptake of FITC-dextran as reported by Makarow (1985). Therefore, we checked our FD batches for impurities before uptake experiments were performed. Gel filtration of FD on a PD10 Sephadex G-25M column, eluted with distilled water, showed that at least $99.9 \%$ of the fluorescence eluted in the void volume (data not shown). The remainder eluted, like free FITC, in the total volume of the column. The amount of fluorescing material in the total volume was not capable of causing detectable cell fluorescence, in contrast to the material eluting at the void volume (data not shown). When intact cells were incubated with an amount of free FITC equivalent to dextran-bound FITC, the cells were clearly labelled. Washed cells were converted to spheroplasts. Washed spheroplasts were lysed and ethanol-precipitated, and the precipitate was applied to the Superose 6 gel filtration column. No fluorescence could be detected in the ethanol precipitate (Fig. $1 c$ ). In summary, the material internalized by cells and spheroplasts is insoluble in $80 \%$ (v/v) ethanol and has the same apparent molecular mass as FD70 (Fig. 1). Therefore we conclude that cells and spheroplasts are capable of internalizing intact FD70. By fluorescence microscopy we found (data not shown) that the fluorescent marker was localized in the vacuole when glucose was available in the incubation mixture. The fluorescent marker was mainly localized in the cytoplasm when glucose was absent, as also reported by Makarow \& Nevalainen (1987).

Incubation of cells at $37^{\circ} \mathrm{C}$ with different concentrations of FD70 showed that FD70 uptake could not be saturated (Fig. 2), which suggests fluid phase uptake of this substrate (Steinman et al., 1974). Since incubation at $0^{\circ} \mathrm{C}$ resulted in background fluorescent labelling of the cells (Fig. 2 ), probably due to the presence of damaged cells, in further experiments all values obtained at $37^{\circ} \mathrm{C}$ were corrected for fluorescence found at $0{ }^{\circ} \mathrm{C}$. The mean uptake rate of fluid phase by intact cells as derived from FD70 uptake was $37 \mathrm{nl}$ per $10^{8}$ cells $^{-1}$ at $\mathrm{pH}>7$, ( $\mathrm{SEM}=6.55$; $n=5$ ). This is in the same order of magnitude as fluid phase endocytosis measured with

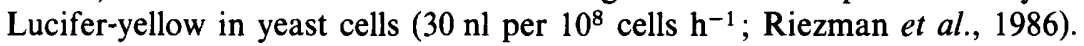

Fig. 2 clearly shows that spheroplasts took up FD70 at a higher rate than intact cells. A further quantitative analysis of this phenomenon is presented in Table 1. Although the absolute increase in FD uptake varied between different experiments due to different cell numbers, the relative increase was reproducible. Spheroplasts showed an almost threefold increase in FD70 uptake as compared to intact cells, indicating that the cell wall acts as a barrier to uptake of FD70. Treatment of intact cells with $100 \mathrm{mM}$-DTT or $250 \mathrm{~mm}$-EDTA resulted in a comparable increase of FD70 uptake (Table 1). Since FD uptake was not affected when spheroplasts were treated with DTT or EDTA (data not shown), the conclusion is that these treatments affect cell-wallrather than membrane-passage by FITC-dextrans. We also treated cells with $\mathrm{LiCl}$ because this is generally used to promote DNA uptake by intact cells (Ito et al., 1983). Treatment with 1 M- 


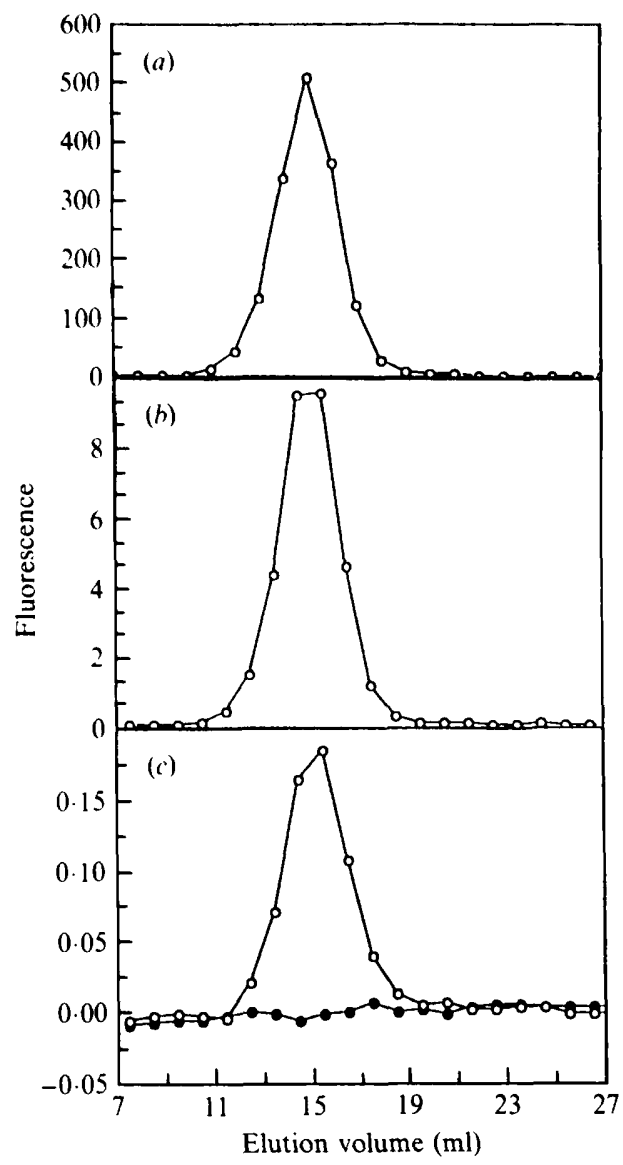

Fig. 1

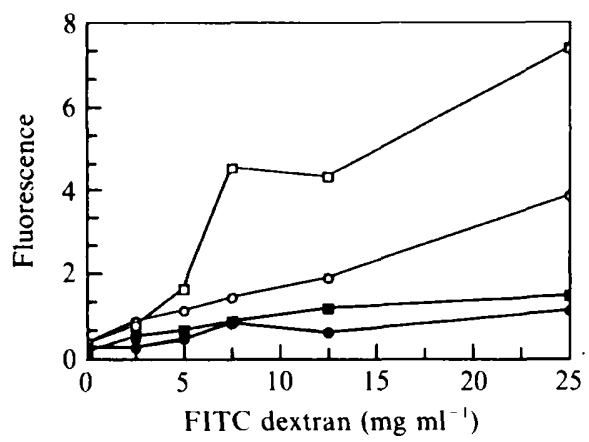

Fig. 2

Fig. 1. Internalization of FITC-dextran by $S$. cerevisiae as determined by gel filtration on a Superose 6 column. (a) Gel filtration of FD70; $(b)$ gel filtration of ethanol-precipitable material internalized by spheroplasts incubated with FD70; $(c)$ gel filtration of ethanol-precipitable material internalized by intact cells incubated with either FD70 (O) or free FITC (O). Collected fractions were assayed fluorometrically. The void volume and total volume of the column were at $8.9 \mathrm{ml}$ and $24.2 \mathrm{ml}$, respectively.

Fig. 2. Concentration-dependent uptake of $70 \mathrm{kDa}$ FITC-dextran. S. cerevisiae intact cells (circles) or spheroplasts (squares) were incubated for $30 \mathrm{~min}$ with different concentrations of $70 \mathrm{kDa}$ FITCdextran in $10 \mathrm{~mm}$-Tris $/ \mathrm{HCl}, \mathrm{pH} \mathrm{7.8}$, at $0^{\circ} \mathrm{C}$ (solid symbols) or $37^{\circ} \mathrm{C}$ (open symbols). FITC-dextran uptake was measured as fluorescence of the incubated cells.

$\mathrm{LiCl}$, which did not affect cell viability, did not result in a significant increase in FD70 uptake (data not shown).

FD150 was not taken up by intact cells, or by DTT- or EDTA-treated cells. However, spheroplasts were capable of taking up FD150 (Table 1), which indicates that the cell wall acts as a barrier to the uptake of FD150.

\section{Release of periplasmic invertase activity}

Invertase activity was induced by transferring cells from $3 \%$ glucose to $0 \cdot 2 \%$ glucose in YPG medium. The periplasmic invertase activity of induced $S$. cerevisiae cells was about 15000 units per $100 \mathrm{mg}$ fresh weight as determined by spheroplasting the cells (Table 2). It is likely that this activity was formed before spheroplast formation, because when spheroplasting was carried out 
Table 1. Increase in FITC-dextran uptake after treatment of yeast cells with DTT or EDTA, or after spheroplasting

Increase in uptake of FITC-dextrans (mean $\pm \mathrm{SEM} ; n=3$ ) is presented as uptake by treated cells divided by uptake by non-treated cells. The basal level of FD70 uptake by intact cells was $0.47 \mu \mathrm{g}$ per $10^{8}$ cells per $30 \mathrm{~min}$.

$\begin{array}{ccc} & \begin{array}{c}\text { Uptake of FITC-dextrans } \\ \text { relative to control cells }\end{array} \\ \text { Treatment } & 70 \mathrm{kDa} & 150 \mathrm{kDa} \\ 100 \mathrm{mM}-\mathrm{DTT} & 3 \cdot 1 \pm 0.51 & \text { No uptake } \\ 250 \mathrm{~mm} \text {-EDTA } & 2.4 \pm 0.58 & \text { No uptake } \\ \text { Spheroplasting } & 2.9 \pm 0.78 & 3.9 \pm 1 \cdot 11^{*}\end{array}$

* Since intact cells did not take up FD150, the increase in uptake of FD150 by spheroplasts compared to intact cells is presented as the ratio of fluorescence of spheroplasts at $37^{\circ} \mathrm{C}$ to the fiuorescence of intact cells at $37^{\circ} \mathrm{C}$.

Table 2. Release of invertase activity into the medium by glucose-derepressed yeast cells

As a control, glucose-repressed cells were treated in the same way as derepressed cells. The medium contained about 50 units of invertase activity and spheroplasting released another 1200 units. The activities of derepressed cells were corrected for these values. Results are the mean \pm SEM of three independent experiments.

\begin{tabular}{|c|c|c|c|}
\hline \multirow[b]{2}{*}{ Treatment } & \multicolumn{2}{|c|}{$\begin{array}{c}10^{-3} \times \text { Invertase activity } \\
\text { (units per } 100 \mathrm{mg} \text { fresh weight) }\end{array}$} & \multirow{2}{*}{$\begin{array}{c}\text { Percentage } \\
\text { released }^{*}\end{array}$} \\
\hline & Released & Retained & \\
\hline $\begin{array}{l}10 \mathrm{~mm} \text {-Tris/HCl, pH } 7.8 \\
\quad+100 \mathrm{~mm} \text {-EDTA } \\
\quad+20 \text { mM-DTT }\end{array}$ & $\begin{array}{l}0.17 \pm 0.02 \\
0.29 \pm 0.07 \\
5.61 \pm 1.5\end{array}$ & $\begin{array}{l}15.2 \pm 0.62 \\
16.4 \pm 1.01 \\
14.4 \pm 4.0\end{array}$ & $\begin{array}{r}1 \cdot 1 \\
1 \cdot 7 \\
28 \cdot 0\end{array}$ \\
\hline
\end{tabular}

* Invertase activity released during cell treatment as a percentage of total (released plus retained) invertase activity.

in the presence of cycloheximide $\left(10 \mu \mathrm{g} \mathrm{ml}^{-1}\right)$, the invertase activity released into the medium did not decrease (data not shown). Glucose-repressed cells contained a 15 -fold lower invertase activity than induced cells.

Only $1.1 \%$ of invertase activity was released into the medium during a $30 \mathrm{~min}$ treatment of the cells with $10 \mathrm{~mm}$-Tris/ $\mathrm{HCl}, \mathrm{pH} 7.8$ (Table 2). When cells were treated in the same way in the presence of $100 \mathrm{mM}$-EDTA, there was a slight increase in release of invertase activity. However, when the cells were treated with $20 \mathrm{mM}$-DTT, almost $30 \%$ of the invertase activity was released into the medium. Comparable treatment of the cells with $1 \mathrm{M}-\mathrm{LiCl}$ did not result in a significant release of invertase activity (data not shown).

The DTT-released invertase activity was analysed by gel filtration (Fig. 3). The molecular mass of DTT-released invertase was $320 \mathrm{kDa}$, which corresponds to the dimeric periplasmic form of invertase (Esmon et al., 1987: Tammi et al., 1987). Invertase activity could not be detected when non-induced cells were treated with DTT (Fig. 3). The invertase activity which was retained by the cells during DTT treatment eluted with an average apparent molecular mass of $590 \mathrm{kDa}$ (Fig. 3).

In the following experiment the effects of EDTA and DTT on the release of cell wall mannoproteins were studied. A 30 min treatment of intact cells with $10 \mathrm{mM}-\mathrm{Tris} / \mathrm{HCl}, \mathrm{pH} 7 \cdot 8$, released about $25 \mu \mathrm{g}$ protein per $100 \mathrm{mg}$ fresh weight. No significant increase was detected when the cells were treated with $100 \mathrm{~mm}$-EDTA in the same buffer. Treatment of the cells with $20 \mathrm{mM}$ DTT resulted in a threefold increase of protein released $(80 \mu \mathrm{g}$ per $100 \mathrm{mg}$ fresh weight). 


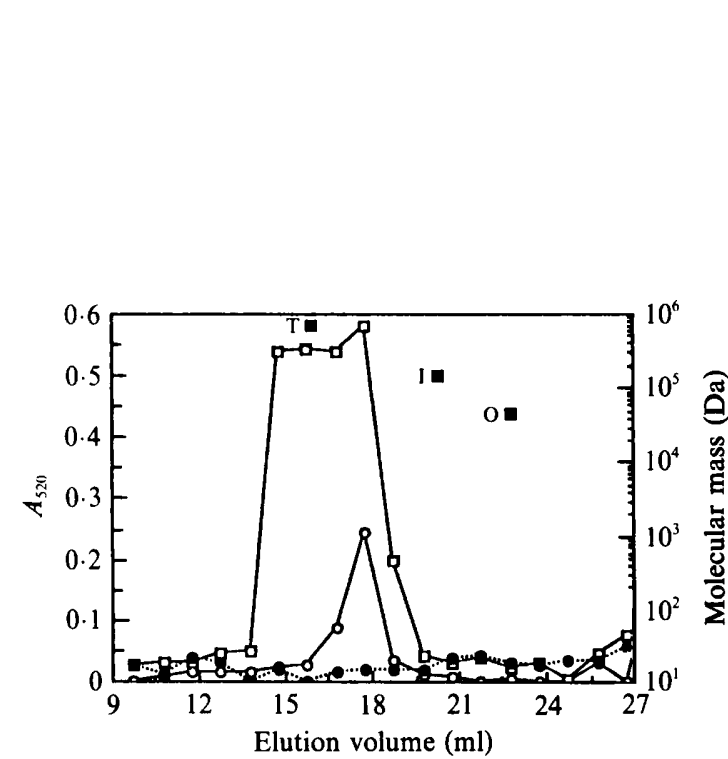

Fig. 3

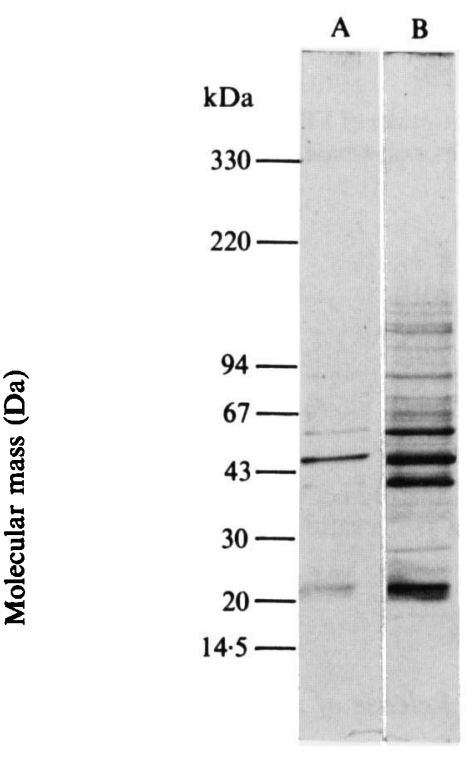

Fig. 4

Fig. 3. Gel filtration of invertase activity released by DTT or subsequent spheroplasting. Derepressed cells $(O)$ and glucose-repressed cells $(O)$ were treated with DTT. Derepressed cells were spheroplasted after DTT treatment $(\square)$. Supernatants were subjected to gel filtration on a TSK G4000SW column and invertase was assayed in the collected fractions. The amount of reducing sugars formed is shown as $A_{520}$. Thyroglobulin (T, $\left.669 \mathrm{kDa}\right), \operatorname{IgG}(\mathrm{I}, 150 \mathrm{kDa})$ and ovalbumin $(\mathrm{O}, 45 \mathrm{kDa})$ were used as molecular mass markers. The void volume and total volume of the column were at $10.7 \mathrm{ml}$ and $27.0 \mathrm{ml}$, respectively.

Fig. 4. Electrophoretic patterns of mannoproteins released from intact yeast cells. The cells were incubated for $30 \mathrm{~min}$ at $4{ }^{\circ} \mathrm{C}$ in: $\mathrm{A}, 10 \mathrm{~mm}-\mathrm{Tris} / \mathrm{HCl}, \mathrm{pH} 7.8$; or $\mathrm{B}, 10 \mathrm{mM}$-Tris/ $\mathrm{HCl}, \mathrm{pH} 7.8$, containing $20 \mathrm{~mm}$-DTT. The samples were run in $2 \cdot 2-20 \%(\mathrm{w} / \mathrm{v})$ SDS-polyacrylamide gradient gels and contained the protein released from $3 \mathrm{mg}$ fresh weight of cells. The positions of molecular mass markers are as indicated $(\mathrm{kDa})$.

Analysis of the extracts by SDS-PAGE (Fig. 4) showed that DTT released many additional polypeptides from intact cells compared to the polypeptides freed by buffer alone. Their molecular masses varied between 20 and $150 \mathrm{kDa}$. None of these treatments affected cell viability (data not shown).

\section{DISCUSSION}

Preston et al. (1987) showed that cell labelling after incubation with FD70 at pH 5.5 could be due to diffusion of contaminating FITC and other low-molecular-mass impurities into the cell instead of being due to endocytosis of FD70. For several reasons, we believe that under our experimental conditions cell labelling was due to endocytotic uptake of FITC-dextrans. First, FD70 was taken up by intact cells but FD150 was not (Table 1), although both FD-batches showed the same degree of contamination with low-molecular-mass fluorescent compounds. Therefore, this low amount of contamination does not seem to be responsible for cell labelling. This was confirmed by the fact that contaminating fluorescent compounds isolated by means of gel filtration, when presented at the same concentration as in FD70-uptake experiments, did not result in labelling of intact cells. Second, intact FD70 was shown to be internalized by spheroplasts and intact cells (Fig. 1). The internalized material was insoluble in $80 \%(\mathrm{v} / \mathrm{v})$ ethanol and eluted in gel filtration at the same position as FD70. Third, as uptake of free FITC is highly $\mathrm{pH}$ dependent, all incubations were performed at $\mathrm{pH} \geqslant 7$. Cell suspensions were shaken during incubation to assure aeration, which explains why the $\mathrm{pH}$ did not drop during the incubation period as was reported by Preston et al. (1987). At neutral pH free FITC is negatively 
charged (Martin \& Lindqvist, 1975) which inhibits membrane-passage by means of diffusion. Fourth, the rate of fluid phase uptake by intact cells $\left(37 \mathrm{nl}\right.$ per $10^{8}$ cells $\mathrm{h}^{-1}$ at $\left.\mathrm{pH}>7\right)$ as calculated from FD70 uptake was in the same order of magnitude as reported for endocytotic uptake as measured with Lucifer-yellow in yeast cells (Riezman, 1985; Riezman et al., 1986). We conclude that yeast cells are capable of endocytosis of FITC-dextrans.

Removal of the cell wall results in a threefold increase in FD uptake (Fig. 2, Table 1), indicating that the cell wall acts as a barrier to FD uptake. A similar result was obtained by Makarow (1985) who showed a fourfold increase in endocytosis of $\alpha$-amylase ( $54.8 \mathrm{kDa}$ ) by spheroplasts compared to intact cells. A considerable increase in uptake of FD70 was also detected when intact cells were treated with $100 \mathrm{~mm}$-DTT or $250 \mathrm{~mm}$-EDTA (Table 1). These treatments did not affect the passage of FITC-dextrans through the membrane but affected passage through the cell wall. Although DTT and EDTA treatments increased cell wall porosity to FD70, they did not make FD150 uptake possible. FD150 was only internalized by spheroplasts (Table 1).

We also used the release of periplasmic invertase to study cell wall porosity. $S$. cerevisiae contains two forms of invertase, a cytoplasmic unglycosylated form which is expressed constitutively and a secreted glycosylated form which is subjected to catabolite repression (Dodyk \& Rothstein, 1964). The secreted invertase is highly retained in the periplasmic space (Esmon et al., 1987; Tammi et al., 1987). A periplasmic invertase of about $320 \mathrm{kDa}$ was released by treatment of cells with DTT (Fig. 3, Table 2). Esmon et al. (1987) showed release of underglycosylated invertase in a mnn 9 mutant after treatment with another thiol reagent, $\beta$ mercaptoethanol. Saccharomyces fragilis invertase could also be released by $\beta$-mercaptoethanol (Kidby \& Davies, 1970).

Most known periplasmic enzymes in yeast have a molecular mass of at least $250 \mathrm{kDa}$ (Tanner \& Lehle, 1987), which might be high enough to retain them in the periplasmic space. However, Esmon et al. (1987) proposed that oligomerization of periplasmic enzymes such as invertase and acid phosphatase prevents leakage of these molecules into the medium. In accord with this proposal, we found that only $28 \%$ of total periplasmic invertase activity was released after DTT treatment (Table 2). The invertase activity retained after DTT treatment was of a higher molecular mass than the DTT-released invertase (Fig. 3).

According to Esmon et al. (1987) no disulphide bonds are involved in invertase oligomerization. We conclude that the reduction of disulphide bridges in the yeast cell wall is responsible for leakage of periplasmic invertase into the medium. This could be due to the formation of pores caused by the release of cell wall proteins (Fig. 4), by a more general opening of the wall due to the reduction of intermolecular disulphide bridges, or both.

There was only a slight increase in invertase release due to treatment with EDTA, although this treatment stimulated the uptake of FITC-dextrans equally as well as did DTT. A possible explanation is that EDTA opens up the wall by the removal of divalent cations which form bridges between negative charges such as the multiple phosphate groups in the mannan sidechains of mannoproteins (Ballou, 1976). Invertase, which itself carries many electrical charges, in contrast to FITC-dextran, might then be retained by interacting with the electrical charges in the mannoprotein layer.

When one compares the Stokes radii of dextran molecules (Granath \& Kvist, 1967) with those of globular proteins (Siegel \& Monty, 1966), $70 \mathrm{kDa}$ dextrans (Stokes radius $5.8 \mathrm{~nm}$ ) are comparable with $400 \mathrm{kDa}$ proteins, and $150 \mathrm{kDa}$ dextrans (Stokes radius $8.2 \mathrm{~nm}$ ) with $2000 \mathrm{kDa}$ proteins. The fact that intact cells are capable of internalizing FD70 suggests that the yeast cell wall is permeable to globular proteins with a molecular mass of about $400 \mathrm{kDa}$. Nevertheless, invertase, of molecular mass $320 \mathrm{kDa}$, can only be released after DTT treatment of intact cells. There are also numerous reports of smaller proteins which are not secreted, or are secreted with low efficiencies, into the medium although plasma membrane passage has occurred (see Introduction). Therefore it seems plausible that not only pore size of the cell wall but also characteristics of the secreted protein other than molecular mass, such as glycosylation and charge, are important in determining whether a secreted protein can pass the yeast cell wall to enter the medium. 
We are indebted to A. J. A. Nederbragt for technical assistance and to Dr A. Koenderman and Professor Dr H. van den Ende for helpful advice.

\section{REFERENCES}

Ballou, C. E. (1976). Structure and biosynthesis of the mannan component of the yeast cell envelope. Advances in Microbial Physiology 14, 93-158.

Basu, J., Kundu, M., MukherJee, K. \& ChakraBARTI, P. (1986). Release of a lectin from a fatty acid auxotroph of Saccharomyces cerevisiae grown in presence of oleic acid. Biochemical and Biophysical Research Communications 136, 596-602.

DAs, R. C. \& Schultz, J. L. (1987). Secretion of heterologous proteins from Saccharomyces cerevisiae. Biotechnology Progress 3, 43-48.

DoDYK, F. \& Rothstein, A. (1964). Factors influencing the appearance of invertase in Saccharomyces cerevisiae. Archives of Biochemistry and Biophysics 104, 478-486.

Esmon, P. C., Esmon, B. E., Schauer, I. E., Taylor, A. \& Schekman, R. (1987). Structure, assembly, and secretion of octameric invertase. Journal of Biological Chemistry 262, 4387-4394.

Goldstein, A. \& LAMPEN, J. O. (1975). $\beta$-D-Fructofuranoside fructohydrolase from yeast. Methods in Enzymology' 42, 504-511.

Granath, K. A. \& Kvist, B. E. (1967). Molecular weight distribution analysis by gel chromatography on Sephadex. Journal of Chromatography 28, 69-81.

Hitzeman, R. A., Leung, D. W., Perry, L. J., Kohr, W. J., Levine, H. L. \& Goeddel, D. V. (1983). Secretion of human interferons by yeast. Science 219 , 620-625.

Ito, H., Fukuda, Y., Murata, K. \& Kimura, A. (1983). Transformation of intact yeast cells treated with alkali cations. Journal of Bacteriology 153, 163168.

KIDBY, D. K. \& DAviES, R. (1970). Invertase and disulphide bridges in the yeast wall. Journal of General Microbiology 61, 327-333.

LAEMMLI, U. K. (1970). Cleavage of structural proteins during the assembly of the head of bacteriophage T4. Nature, London 227, 680-685.

Makarow, M. (1985). Endocytosis in Saccharomyces cerevisiae: internalization of alpha-amylase and fluorescent dextran into cells. EMBO Journal 4, 1861-1866.

Makarow, M. \& Nevalainen, L. T. (1987). Transport of a fluorescent macromolecule via endosomes to the vacuole in Saccharomyces cerevisiae. Journal of Cell Biology 104, 67-75.

Martin, M. M. \& Lindevist, L. (1975). The pH dependence of fluorescein fluorescence. Journal of Luminescence 10, 381-390.

MORRISSEY, J. H. (1981). Silver stain for proteins in polyacrylamide gels: a modified procedure with enhanced uniform sensitivity. Analytical Biochemistry 117, 307-310.

Nishizawa, M., Ozawa, F. \& Hishinuma, F. (1987). Construction of an expression and secretion vector for the yeast Saccharomyces cerevisiae. Agricultural and Biological Chemistry 51, 515-521.

Preston, R. A., Murphy, R. F. \& Jones, E. W. (1987). Apparent endocytosis of fluorescein isothiocyanateconjugated dextran by Saccharomyces cerevisiae reflects uptake of low molecular weight impurities, not dextran. Journal of Cell Biology 105, 1981-1987.

RiezMaN, H. (1985). Endocytosis in yeast: several of the yeast secretory mutants are defective in endocytosis. Cell 40, 1001-1009.

Riezman, H., Chvatchko, Y. \& Howald, I. (1986). Endocytosis in yeast: relationship to other cellular pathways. In UCLA Symposia on Molecular and Cellular Biology, New Series, vol. 33, pp. 443-450. Edited by J. Hicks. New York: Alan R. Liss, Inc.

Rothstein, S. J., Lazarus, C. M., SMITH, W. E., Baulcombe, D. C. \& Gatenby, A. A. (1984). Secretion of a wheat alpha-amylase expressed in yeast. Nature, London 308, 662-665.

ScherRer, R., Louden, L. \& GerhardT, P. (1974). Porosity of the yeast cell wall and membrane. Journal of Bacteriology 118, 534-540.

SiEGEL, L. M. \& MONTY, K. J. (1966). Determination of molecular weights and frictional ratios of proteins in impure systems by use of gel filtration and density gradient centrifugation. Application to crude preparations of sulfite and hydroxylamine reductases. Biochimica et biophysica acta 112, 346-362.

Smith, P. K., Krohn, R. I., Hermanson, G. T., Mallia, A. K., Gartner, F. H., Provenzano, M. D., Fujimoto, E. K., GoEke, N. M., Olson, B. J. \& KLENK, D. C. (1985a). Measurement of protein using bicinchoninic acid. Analytical Biochemistry 150, 76-85.

SMITH, R. A., DuncaN, M. J. \& MoIR, D. T. (1985b). Heterologous protein secretion from yeast. Science 229, 1219-1224.

SpIRo, R. G. (1966). Analysis of sugars found in glycoproteins. Methods in Enzymology 8, 3-26.

Steinman, R. M., Silver, J. M. \& CohN, Z. A. (1974). Pinocytosis in fibroblasts, quantitative studies in vitro. Journal of Cell Biology 63, 949-969.

Tammi, M., Ballou, L., Taylor, A. \& Ballou, C. E. (1987). Effect of glycosylation on yeast invertase oligomer stability. Journal of Cell Biology 262, 43954401.

TANNer, W. \& Lehle, L. (1987). Protein glycosylation in yeast. Biochimica et biophysica acta 906, 81-99.

Wood, C. R., Boss, M. A., Kenten, J. H., Calvert, J. E., Roberts, N. A. \& Emtage, J. S. (1985). The synthesis and in vivo assembly of functional antibodies in yeast. Nature, London 314, 446-449.

Zlotnik, H., Fernandez, M. P., Bowers, B. \& Cabib, E. (1984). Saccharomyces cerevisiae mannoproteins form an external cell wall layer that determines wall porosity. Journal of Bacteriology 159, 1018-1026. 